\title{
Differentiating captive and wild African lion (Panthera leo) populations in South Africa, using stable carbon and nitrogen isotope analysis
}

\author{
Alison Hutchinson ${ }^{1}$ (D) David L. Roberts ${ }^{1}$ (D) \\ Received: 6 June 2019/Revised: 23 March 2020 / Accepted: 30 March 2020/ \\ Published online: 16 April 2020 \\ (C) The Author(s) 2020
}

\begin{abstract}
The international trade in lion (Panthera leo) products, particularly bone, has increased substantially over the last decade. The Convention on International Trade in Endangered Species of Wild Fauna and Flora (CITES) has established a zero-export quota for wildorigin lion bones. Whilst the trade of lion bone is permittable from captive-bred South African populations, there is no established method to differentiate between captive and wild-sourced lion derivatives in trade. This study acts as a preliminary investigation, by examining the stable carbon $\left(\delta^{13} \mathrm{C}\right)$ and nitrogen $\left(\delta^{15} \mathrm{~N}\right)$ isotope composition of hair from wild and captive lion populations as well as wild prey animals in South Africa, to judge the accuracy and applicability of this method for future bone analysis. Isotopic values for $\delta^{15} \mathrm{~N}$ are found to be significantly enriched in some wild populations, however it is not possible to discriminate between captive and wild populations using $\delta^{13} \mathrm{C}$ analysis alone. Using the classification algorithm $k$-Nearest Neighbour, the origin of simulated data was identified with $70 \%$ accuracy. When using the model to test the origin of seized samples, $63 \%$ were classified as of wild origin. Our study indicates the potential for stable isotope analysis to discriminate between captive and wild populations. Additional study of captive husbandry, and analysis of bone samples from populations of a known origin and feeding regime is recommended to improve the utility of this method for maintaining transparency in trade.
\end{abstract}

Keywords CITES · Forensic tool · Hair analysis · Lion-bone trade · Wildlife crime

Communicated by Adeline Loyau.

This article belongs to the Topical Collection: Biodiversity exploitation and use.

Alison Hutchinson

alison.hutchinson@northumbria.ac.uk

1 Durrell Institute of Conservation and Ecology, School of Anthropology and Conservation, University of Kent, Canterbury CT2 7NR, UK 


\section{Introduction}

African lions (Panthera leo) are the only Panthera species to be listed on Appendix II of the Convention on International Trade in Endangered Species of Wild Fauna and Flora (CITES), allowing managed international commercial trade, through a permit system (CITES 2017). Trade in lion parts and derivatives is highly variable, culturally specific, and supplied through legal and illegal means (Williams et al. 2017a; Outhwaite 2018). Whilst the legal trade in lion products is linked to the trophy hunting industry and the legal killing of problematic or dangerous wild lions (Outhwaite 2018), the lucrative, and sometimes brazen illegal market for lion body parts is fuelled by the unlawful killing of both wild and captive-bred lions (CITES 2014; Williams et al. 2017a).

Domestic markets mainly involve the trade in teeth, skin, fat and claws which are used for traditional, medicinal and ceremonial purposes (CITES 2014; Williams et al. 2015; Williams et al. 2017a; Outhwaite 2018). International trade in lion products has largely been dominated by the trophy hunting industry, destined for American and European markets (Outhwaite 2018). However, a growing commercial trade in lion-bone, supplying Asian markets for medicinal and decorative purposes (Williams et al. 2015; Outhwaite 2018), has raised the issue of lion conservation, management, and illegal markets to the global stage.

In 2017, following a 10-year escalation in lion-bone trade, CITES revised the lions Appendix II listing, to prohibit the commercial trade of all wild derived lion bones (CITES 2017; UNEP-WCMC 2017). This revision does not make allowance for the trade in skin, fat and other lion derivatives which are highly sought after in inter-African markets (Outhwaite 2018). South Africa is the only country permitted under CITES regulations to legally trade lion bones, provided they are sourced from captive-bred populations, within annual quota limits (CITES 2017).

South Africa is unique amongst lion range states, home to approximately $17 \%$ ( 3490) of the global wild lion population (Bauer et al. 2018), it also hosts an extensive captive-bred population, established largely for trophy hunting outfitters (Lindsey et al. 2012). Although the full extent of the captive breeding industry is unknown, reports suggest that as many as 300 breeding facilities are in operation (EMS Foundation 2018), with a combined captive population of between 6000 and 8500 individuals (Funston and Levendal 2015; Van der Vyver 2017). The South African CITES Scientific Advisory consider the trade in captive sourced lion bones to be non-detrimental to wild populations, and a sustainable by-product of the trophy hunting industry (Lindsey et al. 2012; Tensen 2016; DEA 2018a).

In the 2 years following the 2017 lion CITES Appendix II annotation, the trading quota has been subject to much controversy, amidst concerns of a developing illegal market (Bauer et al. 2018; Coals et al. 2019; Williams et al. 2019). In June 2017, a quota of 800 lion skeletons was established (DEA 2017). One year later this was increased to 1500 (DEA 2018b), but was quickly reduced to 800 in December 2018, following international objection and fears over the damaging impact on South Africa's conservation reputation (PCEA 2018; Parliament of South Africa 2019). In August 2019 the High Court of Pretoria found the previous quotas to be unlawful, as the welfare of captive-bred lions was not taken into account (NSPCA vs Department of Environmental Affairs 2019).

The legalised trade in lion-bones from captive populations remains a matter of international and scientific debate, as the potential impact of trade on wild populations is not yet known (Williams et al. 2017b; Bauer et al. 2018; Hinsley et al. 2019). Although South 
African lion populations are dispersed and fragmented (Fig. 1), they are considered stable and are nationally classified as 'least concern' by the International Union for Conservation of Nature (IUCN) (Miller et al. 2016). This is not the case in other range states, and lions are globally classified as 'vulnerable' by the IUCN (Bauer et al. 2018). Across West, Central and East Africa, lion populations are in decline, with western subpopulations classified as 'critically endangered' (Henschel et al. 2014). Although only sporadic records of poaching exist in South Africa (Williams et al. 2015), increased poaching activity of both wild and captive lions has been noted following the establishment of the trading quota (Bega 2017; Williams et al. 2017a; Everatt et al. 2019). Poaching of lions is already a threat to the more vulnerable populations outside of South Africa (Williams et al. 2017b; Outhwaite 2018). The emerging international lion-bone trade has the potential to endanger wild populations across their range if not sustainably managed and enforced (Environmental Investigation Agency 2017; Williams et al. 2017b; Everatt et al. 2019).

Currently no established method exists to differentiate between captive and wildsourced lion derivatives (Williams et al. 2015), and concerns have been raised that the legal trade may provide a mechanism in which to launder wild-sourced bones (CITES 2016). It is unknown whether the lion-bone trade is responding to increasing demand or stimulating demand for felid bones, however, following the United States 2016 ban on trophy imports, some captive breeders have implied that they would begin to increase focus towards lion-bone trade (Williams et al. 2017). The presence of skulls in bone exports further suggests that the lion-bone trade has become a distinct industry, separate from trophy hunting, as lion skulls are typically reserved for trophies (EMS Foundation 2018). To improve transparency in the lion-bone trade and safeguard vulnerable wild populations, methodologies to differentiate between legally sourced and illicit trade are essential (Scientific Authority of South Africa 2018).

One forensic methodology that may enable verification of lion derivatives is stable isotope analysis (SIA). Isotopic signatures in tissue remain constant over time and for this reason have been applied extensively in criminal forensic investigations (Rauch et al. 2007; Hurley et al. 2010; Meier-Augenstein 2017). Isotopic compositions of tissues can provide accurate depictions of environmental and chemical processes during tissue synthesis (Meier-Augenstein 2017), giving an indication of the geographical provenance and feeding ecology of an individual (Meier-Augenstein 2017). SIA of animal tissues has been used in a number of wildlife investigations, including identifying illegally harvested cycads (Retief et al. 2014) and tracing the origin of elephant (Loxodonta africana) ivory (van der Merwe et al. 1990) and rhino (Rhinocerotidae spp.) horn (Hall-Martin et al. 1993).

The stable isotopes of carbon $\left(\delta^{13} \mathrm{C} ;{ }^{13} \mathrm{C} /{ }^{12} \mathrm{C}\right)$ and nitrogen $\left(\delta^{15} \mathrm{~N} ;{ }^{15} \mathrm{~N} /{ }^{14} \mathrm{~N}\right)$ are frequently utilised in feeding ecology studies (Stewart et al. 2003; Parng et al. 2014; Blanke et al. 2017). Through the process of digesting and assimilating foods, both $\delta^{13} \mathrm{C}$ and $\delta^{15} \mathrm{~N}$ become enriched in consumer tissues (Hobson 1999). This diet-tissue fractionation between trophic levels is typically within the range of $+1-2 \%$ for $\delta^{13} \mathrm{C}$ and $+3-4 \%$ for $\delta^{15} \mathrm{~N}$ (Meier-Augenstein 2017). By incorporating consumer and prey isotope compositions into dietary mixing models, the relative contribution of different food sources in a consumer's diet can be determined (DeNiro and Epstein 1978, 1981; Hobson 1999; Darimont et al. 2007; Kawanishi et al. 2012).

Providing that captive and wild lion populations utilise isotopically distinct food sources, $\delta^{13} \mathrm{C}$ and $\delta^{15} \mathrm{~N}$ analysis may provide a novel means to distinguish between both populations. Animals raised in captivity typically have restricted diets compared to the more varied and complex diets in wild food chains (Kays and Feranec 2011). Wild adult 
lions preferentially hunt prey between 190 and $550 \mathrm{~kg}$, this includes species such as gemsbok (Oryx gazella), buffalo (Syncerus caffer), wildebeest (Connochaetes spp.), giraffe (Giraffa spp.) and zebra (Equus quagga) (Hayward and Kerley 2005). This complexity within diets broadens the range of $\delta^{13} \mathrm{C}$ in consumer tissues (DeNiro and Epstein 1978). Although husbandry conditions within South Africa's lion breeding facilities is unknown, unofficial sources suggest domesticated livestock such as poultry and donkey are commonly used (NSPCA 2017, Anon., pers. comm., 2018). Domesticated animals often display enriched $\delta^{15} \mathrm{~N}$ values compared to their wild counterparts, due to the use of agricultural foodstuffs and the application of fertilisers within their diet (Deniro and Epstein 1981; Hu et al. 2009).

This preliminary study will investigate if the origin (wild vs. captive) of lion hair can be accurately assessed through $\delta^{13} \mathrm{C}$ and $\delta^{15} \mathrm{~N}$ isotope analysis. Lion hair is used as a proxy for bone as it can be obtained in a quick, non-invasive manner. While hair is metabolically inert after synthesis, reflecting short-term dietary information from the time of synthesis, bone has a longer turnover rate and remains metabolically active, reflecting dietary inputs over an animal's lifetime (Meier-Augenstein 2017). Although bone has the potential to be enriched in both $\delta^{13} \mathrm{C}$ and $\delta^{15} \mathrm{~N}$ to a greater extent than hair, both tissues are good indicators of diet (O'Connell et al. 2001).

\section{Methods}

\section{Study sites and sampling}

The study was principally conducted on South African lion populations, with additional samples from the UK Border Force and the Powell-Cotton Museum in the UK. Sample collection took place during January and May 2018, except for site 2 populations (Fig. 1) which were routinely collected by staff over many years. All samples were collected using the following protocol. Approximately 10-20 hairs of around $5 \mathrm{~cm}$ in length were cut as close to the base of the hair as possible. Longest lengths of hair were selected where possible, with preference given to the mane and tail. Samples were stored at room temperature, untreated, in plastic bags prior to transportation.

\section{South Africa sample collection}

South African lion samples are categorised into 'wild', 'captive' and 'free-range' groups (Table 1). Of the wild group, 46 individual samples were opportunistically collected by field ecologists at four reserves across South Africa (Fig. 1). Taxidermists operating in the Eastern Cape and Gauteng provinces collectively provided 7 wild origin, 11 captive and 5 free-range lion samples. Free-range lions are typically released from captivity into a wild environment prior to being hunted (Lindsey et al. 2012). Regulations on release period vary by province and can range from 96 hours to 6 months (Williams et al. 2015). While all captive and free-range lions are of South African origin, their precise geographical location is unknown, as is the duration that free-range lions would have had access to wild prey. Preservation methods used at both facilities involve salting the lion hides and tanning in a Lutan FN solution (an aluminium tanning agent).

Prey animal hair was also collected from sampling sites 3 and 4. Additional prey samples were collected during game translocation operations in the KwaZulu Natal province (site 5), for full details on prey species see Table 2. All samples were obtained during 


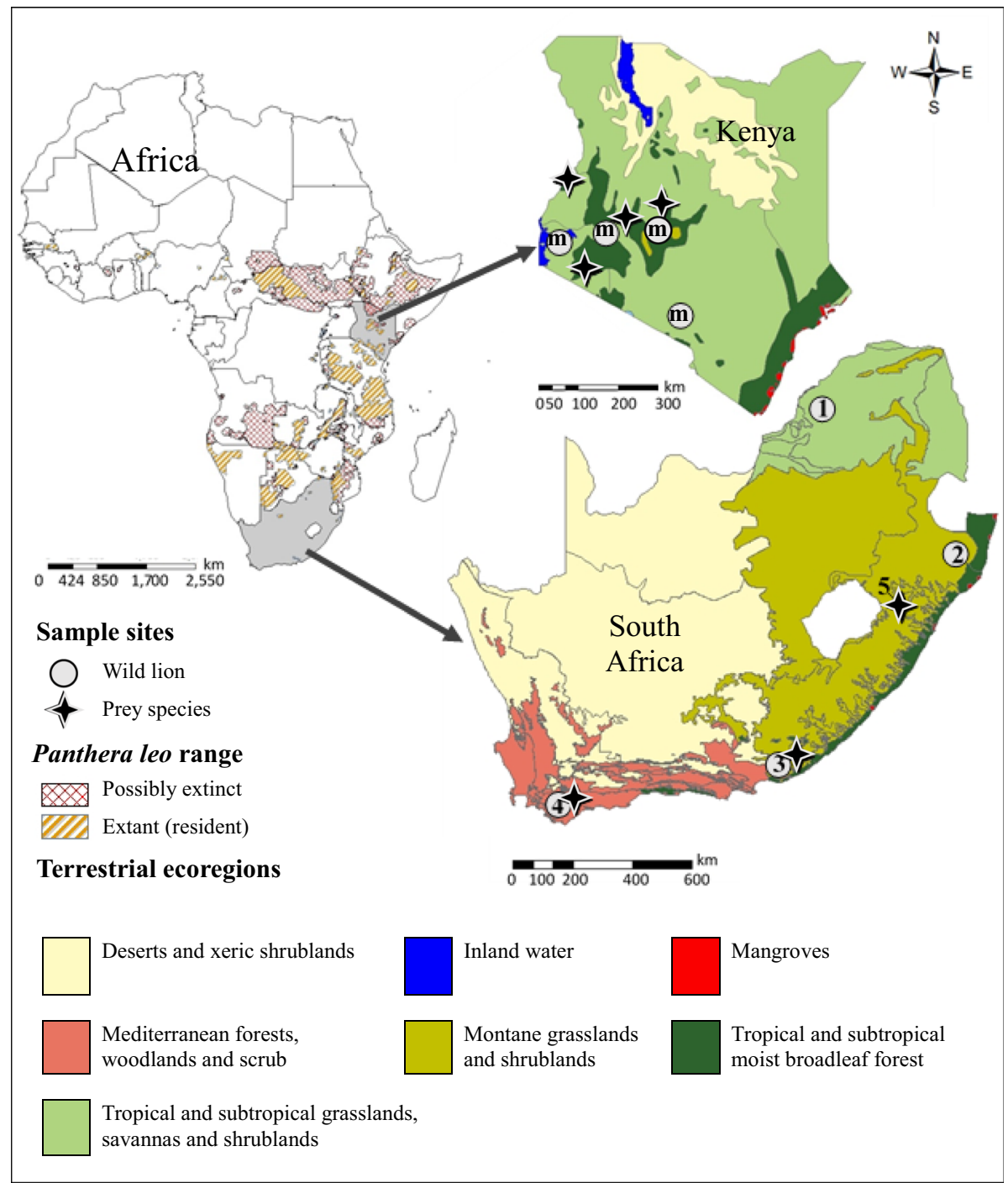

Fig. 1 Study sites. Lion and prey animal samples originating from Kenya were obtained from museum (m) collections in the UK. South African samples were collected from four reserves across the lions' range, spanning the Limpopo, KwaZulu Natal, Eastern and Western Cape provinces. Shaded areas represent lion population distribution across Africa (Panthera and WCS 2016) and terrestrial ecoregions in both Kenya and South Africa (The Nature Conservancy 2009)

routine veterinary or transport procedures, with the exception of one sample which was obtained from a deceased lion.

\section{UK sample collection}

UK samples are split into 'museum' and 'seized' groups. Museum samples were provided by the Powell-Cotton Museum and include the preserved skins of four wild lion and ten 
Table $1 \delta^{13} \mathrm{C} \%$ and $\delta^{15} \mathrm{~N} \%$ composition of whole hair from each testing group

\begin{tabular}{|c|c|c|c|c|c|c|c|}
\hline \multirow[b]{2}{*}{ Group } & \multirow[b]{2}{*}{$\mathbf{n}$} & \multicolumn{3}{|c|}{$\delta^{13} \mathrm{C}(\% \circ)$} & \multicolumn{3}{|c|}{$\delta^{15} \mathrm{~N}(\% \circ)$} \\
\hline & & Mean & SD & Range & Mean & SD & Range \\
\hline Wild & 53 & -11.69 & 2.04 & $-17.88--9.28$ & 11.35 & 1.29 & $6.64-14.98$ \\
\hline Site 1 & 5 & -10.01 & 0.62 & $-10.52--9.28$ & 10.92 & 0.16 & $10.73-11.13$ \\
\hline Site 2 & 36 & -12.13 & 1.85 & $-17.88--9.59$ & 11.51 & 0.90 & $10.13-14.42$ \\
\hline Site 3 & 4 & -12.54 & 0.18 & $-12.69--12.29$ & 12.73 & 0.07 & $12.67-12.81$ \\
\hline Site 4 & 1 & -16.66 & -- & -- & 14.98 & -- & -- \\
\hline Taxidermy wild & 7 & -10.82 & 1.52 & $-13.38--9.54$ & 10.70 & 1.20 & $8.83-11.86$ \\
\hline Museum lion & 4 & -8.69 & 2.10 & $-10.02--5.57$ & 10.08 & 2.67 & $6.64-12.22$ \\
\hline Prey & 14 & -14.26 & 7.18 & $-26.96--9.47$ & 6.78 & 1.82 & $4.96-11.23$ \\
\hline Site 3 & 1 & -12.22 & -- & -- & 6.56 & -- & -- \\
\hline Site 4 & 5 & -20.51 & 2.68 & $-23.29--16.77$ & 8.77 & 1.79 & $6.35-11.23$ \\
\hline Site 5 - game capture & 8 & -19.33 & 7.37 & $-26.96--9.47$ & 6.54 & 0.95 & $4.96-8.10$ \\
\hline Museum prey & 14 & -9.28 & 4.20 & $-19.39--6.21$ & 6.23 & 1.87 & $3.89-9.06$ \\
\hline Captive & 11 & -12.59 & 1.53 & $-14.52--10.45$ & 10.16 & 1.24 & $7.92-11.84$ \\
\hline Free-range & 5 & -12.85 & 1.22 & $-14.19--11.46$ & 10.09 & 1.23 & $8.88-11.65$ \\
\hline Seized & 2 & -12.73 & 1.07 & $-13.48--11.97$ & 9.71 & 0.83 & $9.12-10.29$ \\
\hline
\end{tabular}

Table 2 Prey animals by site

\begin{tabular}{|c|c|c|c|c|}
\hline \multirow[t]{2}{*}{ Location } & \multicolumn{2}{|c|}{ Browsers } & \multicolumn{2}{|c|}{ Grazers } \\
\hline & $\mathrm{n}$ & Species & $\mathrm{n}$ & Species \\
\hline Site 3 & - & - & 1 & Zebra; Equus quagga \\
\hline \multirow[t]{2}{*}{ Site 4} & 1 & $\begin{array}{l}\text { Common duiker; Sylvicapra } \\
\text { grimmia }\end{array}$ & 11 & Springbok; Antidorcas marsupialis \\
\hline & 1 & Giraffe; Giraffa camelopardalis & 2 & Zebra; Equus quagga \\
\hline \multirow{3}{*}{$\begin{array}{l}\text { Site } 5 \text {-game } \\
\text { capture }\end{array}$} & 3 & Bushbuck; Tragelaphus scriptus & 1 & Waterbuck; Kobus ellipsiprymnus \\
\hline & 1 & Kudu; Tragelaphus strepsiceros & 1 & $\begin{array}{l}\text { Blue wildebeest; Connochaetes } \\
\text { taurinus }\end{array}$ \\
\hline & 1 & Eland; Tragelaphus oryx* & 1 & Zebra; Equus quagga \\
\hline \multirow[t]{5}{*}{ Museum } & 1 & Kudu; Tragelaphus strepsiceros & 1 & Ugandan kob; Kobus kob thomasi \\
\hline & & & 3 & Hartebeest; Alcelaphus buselaphus \\
\hline & & & 1 & Reedbuck; Redunca arundinum \\
\hline & & & 3 & Waterbuck; Kobus ellipsiprymnus \\
\hline & & & 1 & Zebra; Equus quagga \\
\hline
\end{tabular}

Categorised into browsers and grazers. One mixed feeder was sampled, denoted with (*)

prey animals (Table 1). All samples originated from Kenya (Fig. 1) and were collected between 1902 and 1903. Preservation methods are unclear, however powdered alum and turpentine were used for skin preservation at the time (Ward 1883). The UK Border Force 
also supplied two samples from seized lion mounts. CITES export documentation identify one of the samples as being captive-bred, and both samples originated from South Africa.

\section{Laboratory procedures}

All samples were analysed for $\delta^{13} \mathrm{C}$ and $\delta^{15} \mathrm{~N}$ isotopic composition between May and July 2018. South African samples were analysed at the Mammal Research Institute Isotope Laboratory at the University of Pretoria. UK samples were analysed at the Bloomsbury Environmental Isotope Facility at the University College London. To investigate interlaboratory accuracy, UK museum samples from kudu (Tragelaphus strepsiceros), waterbuck (Kobus ellipsiprymnus), hartebeest (Alcelaphus buselaphus) and zebra (Equus quagga) were comparatively tested at both facilities.

Pre-treatment and preparation procedures were the same across laboratories. Hair samples were repeatedly rinsed to remove surface contaminants, following protocols outlined in O'Connell and Hedges (1999) and Meier-Augenstein et al. (2011). Whole hairs were then homogenised and aliquots of $0.5-0.6 \mu \mathrm{g}$ were measured into tin capsules. Both UK and South African samples were combusted on a Flash EA 1112 elemental analyser, coupled to a Delta V Plus continuous-flow isotope ratio mass spectrometer (Thermo ${ }^{\circledR}$ ).

Stable isotope ratios are reported in the delta $(\delta)$ notation and expressed relative to the international standard; V-PDB (Vienna Pee Dee Belemnite) for ${ }^{13} \mathrm{C}$, and atmospheric N2 (air) for ${ }^{15} \mathrm{~N}$. All results are reported in parts per thousand (\%o) relative to the international standard using the following equation:

$$
\delta \mathrm{X}=[(\text { Rsample } / \text { Rstandard })-1],
$$

where $\mathrm{X}$ is the element of interest $\left({ }^{13} \mathrm{C}\right.$ or $\left.{ }^{15} \mathrm{~N}\right)$ and Rsample and Rstandard are the ratio of the heavier to lighter isotope $\left({ }^{13} \mathrm{C} /{ }^{12} \mathrm{C}\right.$ or $\left.{ }^{15} \mathrm{~N} /{ }^{14} \mathrm{~N}\right)$, for the sample and international standard respectively.

South African isotope sequences were run in batches of 11 followed by a blank and two in-house reference materials (RMs) (Merck Gel: $\delta^{13} \mathrm{C}=-20.26 \%, \delta^{15} \mathrm{~N}=7.89 \%$ and DL-Valine: $\delta^{13} \mathrm{C}=-10.57 \%$ o, $\delta^{15} \mathrm{~N}=-6.15 \%$ ). Each batch includes one replicate to ensure reproducibility of results. The average uncertainty of repeats is $\delta^{13} \mathrm{C} \pm 0.29 \%$ and $\delta^{15} \mathrm{~N} \pm 0.13 \%$ o $(\mathrm{n}=20)$. Samples were scale-normalised using the in-house RMs, which have been calibrated to the international scale against secondary RMs (NIST 1577b: $\delta^{13-}$ $\mathrm{C}=-21.60 \%$ o $\pm 0.08, \delta^{15} \mathrm{~N}=7.78 \%$ o \pm 0.20 , NIST 2976: $\delta^{13} \mathrm{C}=-18.44 \% \pm 0.10$, $\delta^{15} \mathrm{~N}=6.74 \%$ o $\pm 0.20 \quad$ and $\quad$ NIST $\quad 1547: \quad \delta^{13} \mathrm{C}=-25.98 \% \pm 0.08, \quad \delta^{15-}$ $\mathrm{N}=2.08 \% \pm 0.20)$. NIST delta values have been determined through repeated inter-lab measurements (Hall 1999). Carbon and nitrogen ratios for all in-house and secondary RMs have been calibrated against primary standards (NBS 22: $\delta^{13} \mathrm{C}=-30.03 \%$, IAEA-CH3: $\delta^{13} \mathrm{C}=-24.72 \%$, IAEA-CH6: $\delta^{13} \mathrm{C}=-10.45 \%$, IAEA-CH7: $\delta^{13} \mathrm{C}=-32.15 \%$, IAEA-N $1: \quad \delta^{15} \mathrm{~N}=+0.40 \%$, IAEA-N2: $\quad \delta^{15} \mathrm{~N}=+20.30 \%$ and IAEA-NO3: $\delta^{15-}$ $\mathrm{N}=+4.70 \%$ ). Analytical precision, the standard deviation (SD) from replicate analysis of DL-Valine, is $\delta^{13} \mathrm{C} \pm 0.07 \%$ and $\delta^{15} \mathrm{~N} \pm 0.09 \%$.

UK isotope sequences were run in batches of 10 , with each sample analysed in replicate. The average uncertainty of replicates is $\delta^{13} \mathrm{C} \pm 0.37 \%$ and $\delta^{15} \mathrm{~N} \pm 0.51 \%$ o $(\mathrm{n}=10)$. Sample batches were run in between sets of in-house RMs (OEA Alanine: C\% $=40.44$, $\mathrm{N} \%=15.72 \%$ ) used for quality control, and secondary RMs (ANU: $\delta^{13} \mathrm{C}=-10.45 \%$, USGS-24: $\quad \delta^{13} \mathrm{C}=-16.05 \%$; IAEA-N1: $\quad \delta^{15} \mathrm{~N}=+0.40 \%$; IAEA-N2: $\delta^{15-}$ $\mathrm{N}=+20.30 \%$; IAEA-600: $\delta^{13} \mathrm{C}=-27.77 \%$, $\delta^{15} \mathrm{~N}=+1.00 \%$ and USGS-40: 
$\delta^{13} \mathrm{C}=-26.39 \%$, $\delta^{15} \mathrm{~N}=-4.52 \%$ o) used to calibrate samples to the international scale. USGS-40 was also run midway through the sample sequences to determine analytical precision, this is $\delta^{13} \mathrm{C} \pm 0.14 \%$ and $\delta^{15} \mathrm{~N} \pm 0.003 \%$. Blank samples were also analysed for quality control. Where sample repeats have been run, the mean delta value has been reported in results.

In both laboratories, the RMs used as scale anchors have narrow ranges, which impact accuracy of scale-normalisation and inter-laboratory comparability (Meier-Augenstein and Schimmelmann 2019). While it is possible to compare the results within the study, results are applicable solely to the samples studied.

\section{Statistical analysis}

Statistical analysis was carried out using R, Version 3.4.3 (R Core Team 2018). Analysis is primarily split into five test groups; (i) wild, (ii) captive, (iii) free-range (iv) museum and (v) seized. For further analysis, the wild group is split by each wild sampling site (Table 1). As some of the testing groups display non-normal distributions and unequal variances, the nonparametric Kruskal-Wallis $(\mathrm{K}-\mathrm{W})$ test was used to evaluate results, and the Dunn's test was applied for post-hoc comparisons of groups. To account for the small sample sizes of sites 3 and 4, these groups were additionally combined into a 'Southern-lion' group for K$\mathrm{W}$ testing. The dietary mixing models 'simmr' and 'SIBER' were used to investigate the feeding ecology of each group (Jackson and Parnell 2011; Parnell 2016). Prey isotopic data has been corrected for diet-tissue enrichment, using discrimination factors of $+1.1 \%$ for $\delta^{13} \mathrm{C}$ and +3.5 for $\delta^{15} \mathrm{~N} \%$, as identified in Parng et al. (2014). Isotopic mixing plots of wild lion and prey groups were then modelled to assess the potential contribution of different prey sources in lion populations.

The $k$-Nearest Neighbour (KNN) classification algorithm has been used to assess if samples can be assigned to their correct group based on their isotopic signatures. To address the small sample size, data points have been simulated using the mean and SD of each group (wild, captive, free-range and museum). Each group size was increased to 250, giving an overall sample size of 1000 . The simulated wild group was generated from site 1 $(n=63)$, site $2(n=63)$, site $3(n=62)$, and taxidermy wild $(n=62)$ samples. Site 4 was excluded as it had only one lion sample. Simulated data were then normalised between 0 and 1 before running the KNN algorithm. Simulated seized data $(n=250)$ was then applied to the KNN model, using the above approach. However, as the original seized group was small $(n=2)$, this could potentially allow the SD to cluster the data. Simulated museum samples were excluded from the second KNN model as the seized samples originated from South Africa. When running the KNN model, $90 \%$ of the simulated data was randomly selected as 'training data' and $10 \%$ as 'test data'. The KNN model was most accurate in classifying test data at $k=31$, the square root of sample size $(n=1000)$.

\section{Results}

\section{Isotopic composition between testing groups}

Most testing groups were approximately normally distributed in $\delta^{13} \mathrm{C}$ and $\delta^{15} \mathrm{~N}$ isotope composition (Shapiro-Wilk: $\mathrm{p}>0.05$ ). Exceptions to this were site 2 and museum groups, where a large isotopic range prevents an approximately normal distribution from being assumed (Table 1). 
Boxplots (Fig. 2) show variations in the in $\delta^{13} \mathrm{C}$ and $\delta^{15} \mathrm{~N}$ between lion groups. Although a high variation in $\delta^{13} \mathrm{C}$ was seen amongst samples, there was little overlap between captive, site 1 , and museum samples (Fig. 2a). The mean $\delta^{13} \mathrm{C}$ for the combined

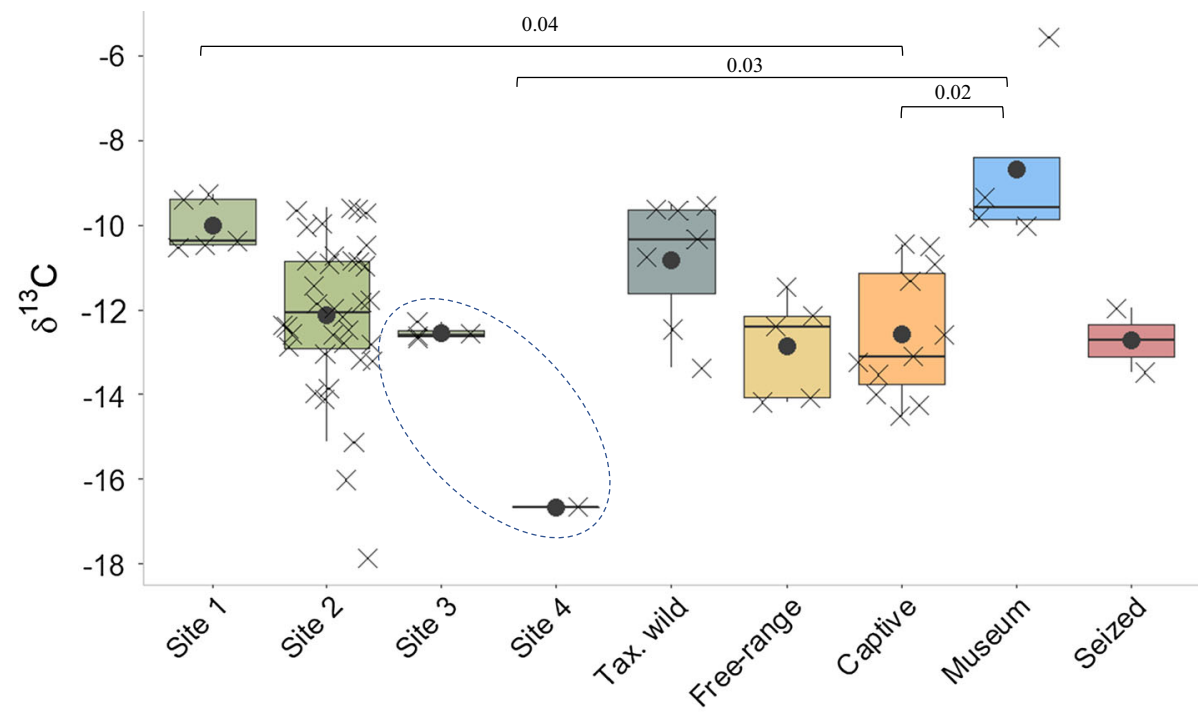

A Testing group

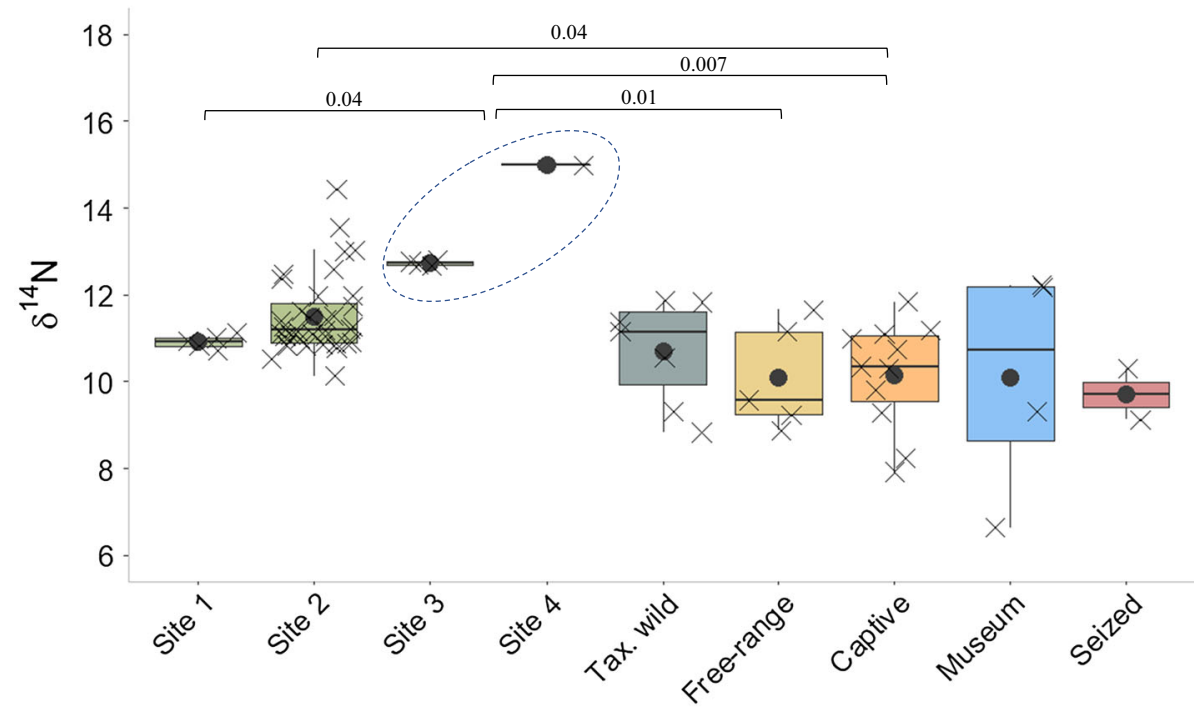

B Testing group

Fig. 2 Boxplots for $\delta^{13} \mathrm{C}$ (a) and $\delta^{15} \mathrm{~N}$ (b) compositions of lion hair, showing individual lion points (crosses), mean (shaded circle), median line and significant differences at the $95 \%$ level. Upper and lower limit whiskers extend $1.5 \times$ the interquartile range (or minimum and maximum extremes). 'Southern' lion grouping indicated with dashed ellipse 
wild testing group was slightly enriched compared to captive and free-range groups at $-11.69 \%$ o $(\mathrm{SD}=2.04 \%$ o $)$ compared with $-12.59 \%$ o $(\mathrm{SD}=1.53 \%$ o $)$ and -12.85 $(\mathrm{SD}=1.22 \%$ ) respectively (Table 1$)$. Although slightly higher $\delta^{13} \mathrm{C}$ was seen in the combined wild group compared to captive and free-range, the difference was not statistically significant. However, when subsets of each wild sampling location were analysed, a significant difference was found between sites $(\mathrm{K}-\mathrm{W}: \mathrm{H}(6)=24.09, \mathrm{p}<0.05)$. Post-hoc analysis revealed a significant difference between wild site 1 and captive groups $(\mathrm{p}=0.04)$. A significant difference was also found between Southern-lion (wild groups 3 and 4$)$ and museum lions ( $\mathrm{p}=0.03$ ), as well as between museum and captive lion populations $(\mathrm{p}=0.02)$.

The mean $\delta^{15} \mathrm{~N}$ in wild populations was 11.35 ( $\mathrm{SD}=1.29 \%$ ). Captive, free-range and seized samples are characterised by decreased $\delta^{15} \mathrm{~N}$ compared to wild populations, at 10.16 $(\mathrm{SD}=1.24 \%), 10.09(\mathrm{SD}=1.23 \%$ ) and $9.71(\mathrm{SD}=0.83 \%$ o $)$ respectively $($ Fig. $2 \mathrm{~b}) . \mathrm{A}$ significant difference between wild and captive groups was found $(\mathrm{K}-\mathrm{W}: \mathrm{H}(6)=22.94$, $\mathrm{p}<0.05)$. Site 2 populations were significantly enriched in $\delta^{15} \mathrm{~N}$ compared to the captive lion samples $(\mathrm{p}=0.04)$. A similar trend was seen in the Southern-lion grouping, which were significantly enriched in $\delta^{15} \mathrm{~N}$ compared to the captive and free-range groups $(\mathrm{p}=0.007$ and $\mathrm{p}=0.01$ respectively). Site 1 lions also differed significantly from the Southern-lion group $(\mathrm{p}=0.04)$. No statistically significant difference in $\delta^{15} \mathrm{~N}$ was found between South African and museum populations.

\section{Dietary mixing model}

Wild lion and prey samples were modelled to estimate lion dietary compositions (Fig. 3). As the site 4 lion $(n=1)$ plots outside the dietary mixing polygon, it was not included within the model. Even with a priori source aggregation, there was a high overlap between prey sources, and the resulting model struggled to differentiate between similar prey groups, particularly South African grazers and museum grazers. Despite this, a clear distinction was seen between browsers and grazers (Fig. 3), indicating that wild lions potentially consume higher proportions of grazing prey.

Both captive and free-range lion groups plotted within the dietary mixing polygon, indicating potential similarity between wild and captive diets. Both captive and free-range lions were slightly depleted in $\delta^{13} \mathrm{C}$ and $\delta^{15} \mathrm{~N}$ (Fig. 3), potentially indicative of different dietary sources, although this cannot be confirmed with the samples here. Additional data from domesticated animals show an overlap between wild and domesticated prey sources (Fig. 3, plots A-F). However, these have not been included in the model due to differing sampling locations and procedures.

\section{Simulated data}

The KNN model was applied to simulated lion groups to test origin classification accuracy. The model was moderately successful in identifying South African wild populations, producing $70 \%$ accuracy (Table 3). High accuracy was found when distinguishing museum samples from South African samples (83\% accuracy), however the model struggled to differentiate between captive populations, misclassifying $55 \%$ of the data. Simulated seized data was also applied to the model. Here, $63 \%$ of the samples were predicted to be of wild origin, $33 \%$ of captive origin and $4 \%$ free-range (Table 3 ). 


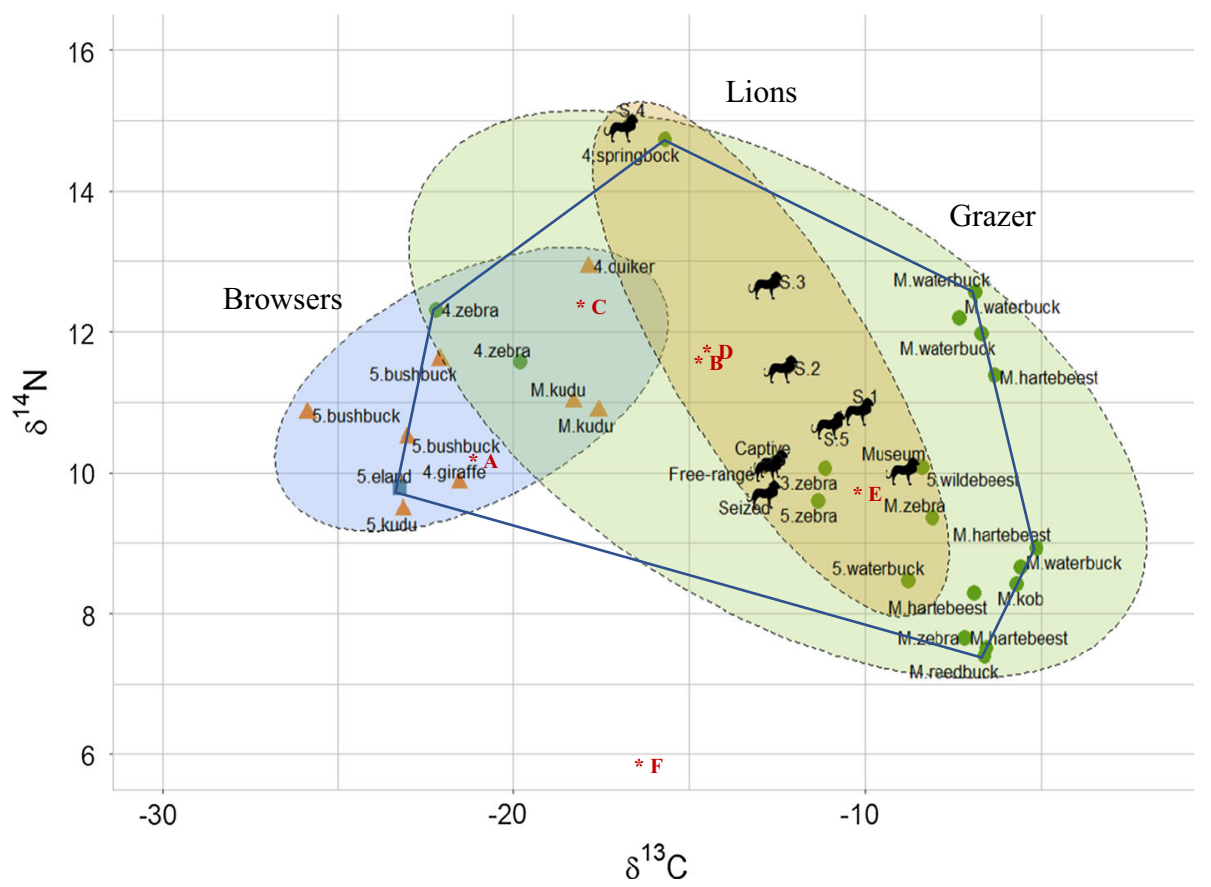

Fig. 3 Isotopic mixing plot of $\delta^{13} \mathrm{C} \%$ and $\delta^{15} \mathrm{~N} \%$ for lion and prey groups, showing lion group averages, standard ellipses (dashed lines) and dietary mixing polygon for lion samples (solid polygon). Prey are split by grazers (shaded circles), browsers (shaded triangles) and mixed feeders (shaded square), subset by sampling location (1-5 and $\mathrm{M}$ for museum), see Table 2 for groupings. Additional domesticated prey are depicted as shaded stars (A-F). Here, 'A-C' are South African lamb (meat) samples from Rûens, Free State and Central Karoo respectively (Erasmus et al. 2016). 'D, E' are donkey (meat) samples from Namibia (Voigt et al. 2014) and donkey (bone/tooth collagen) samples from Kenya (Ambrose and DeNiro 1986). 'F' is a chicken (meat, non-lipid extracted) sample from Pretoria, South Africa (Mutirwara et al. 2018). All dietary data have added discrimination factors of $+1.1 \%$ for $\delta^{13} \mathrm{C}$ and +3.5 for $\delta^{15} \mathrm{~N}$ (Parng et al. 2014)

Table 3 Results of KNN confusion matrix $(\mathrm{n}=100, \mathrm{~K}=31)$. Accuracy shown in bold $(70 \%)$ is the proportion of correctly classified samples, divided by the number of total samples, where wild $=27$, captive $=20$, freerange $=29$, museum $=24$

\begin{tabular}{llllll}
\hline & \multicolumn{2}{l}{ Predictions } & \multirow{2}{*}{ Accuracy } \\
\cline { 2 - 5 } & Wild & Captive & Free-range & Museum & \\
\hline Wild & $\mathbf{1 9}$ & 3 & 4 & 1 & $70 \%$ \\
Captive & 3 & $\mathbf{9}$ & 6 & 2 & $45 \%$ \\
Free-range & 2 & 4 & $\mathbf{2 2}$ & 1 & $75 \%$ \\
Museum & 1 & 3 & 0 & $\mathbf{2 0}$ & $83 \%$ \\
Seized & 158 & 82 & 10 & - & - \\
\hline
\end{tabular}

\section{Interlaboratory findings}

Slight interlaboratory variation, outside of the analytical error range of both laboratories, was seen between duplicates (Table 4). In all cases, analysis in South Africa resulted in a slight enrichment of $\delta^{15} \mathrm{~N} \%$ compared to UK analysis. Although $\delta^{13} \mathrm{C} \%$ composition varied between sites, this variation was not specific to the location of testing. 
Table 4 Interlaboratory comparisons of duplicate prey samples, analytical error is indicated by \pm , SD of duplicates given in brackets

\begin{tabular}{|c|c|c|c|c|c|c|}
\hline \multirow[t]{2}{*}{ Sample } & \multicolumn{2}{|l|}{ UK } & \multicolumn{2}{|l|}{ South Africa } & \multicolumn{2}{|l|}{ Average } \\
\hline & $\begin{array}{c}\delta^{13} \mathrm{C}(\%) \\
\pm 0.13 \%\end{array}$ & $\begin{array}{c}\delta^{15} \mathrm{~N}(\%) \\
\pm 0.004 \%\end{array}$ & $\begin{array}{c}\delta^{13} \mathrm{C}(\%) \\
\pm 0.07 \% 0\end{array}$ & $\begin{array}{c}\delta^{15} \mathrm{~N}(\%) \\
\pm 0.09 \% 0\end{array}$ & $\delta^{13} \mathrm{C}(\%)$ & $\overline{\delta^{15} \mathrm{~N}(\%)}$ \\
\hline Waterbuck & $-8.39(0.24)$ & $8.70(0.21)$ & -7.95 & 9.06 & $-8.17(0.31)$ & $8.88(0.25)$ \\
\hline Hartebeest & $-6.51(1.55)$ & $4.15(0.39)$ & $-7.98(0.49)$ & $4.79(0.45)$ & $-7.25(1.04)$ & $4.47(0.46)$ \\
\hline Kudu & $-18.69(0.09)$ & $7.37(0.05)$ & -19.39 & 7.51 & $-19.04(0.50)$ & $7.44(0.10)$ \\
\hline Zebra & $-7.66(1.76)$ & $5.48(1.98)$ & -8.24 & 4.15 & $-7.95(0.41)$ & $4.82(0.94)$ \\
\hline
\end{tabular}

\section{Discussion}

\section{Isotopic variation between groups}

Stable isotope analysis has demonstrated success in wildlife provenance determination studies (van Schingen et al. 2016; Dittrich et al. 2017). Although few studies have focussed on modern-day lion populations, $\delta^{13} \mathrm{C}$ and $\delta^{15} \mathrm{~N}$ analysis of bone collagen and hair have shown dietary changes and prey preferences in lions (Yeakel et al. 2009; Bocherens et al. 2011). This study aimed to assess if captive-bred and wild lion populations could be accurately differentiated through $\delta^{13} \mathrm{C}$ and $\delta^{15} \mathrm{~N}$ analysis of hair, due to differences in diet between populations.

The South African wild lion groups displayed larger ranges in both $\delta^{13} \mathrm{C}$ and $\delta^{15} \mathrm{~N}$ compositions compared to their captive and free-range counterparts. Smaller isotopic ranges have been attributed restrictive diets in captivity, compared to the higher variation of prey sources in the wild (van Schingen et al. 2016). The high variability in $\delta^{13} \mathrm{C}$ between wild lion sampling locations, both in South Africa and Kenya, is likely to reflect the high complexity of wild diets and range of terrestrial habitats between sites (Fig. 1). The nonnormal distribution seen in site 2 populations may reflect temporal, seasonal or dietary variations, as the samples have been collected over a longer time period, with the greatest number of individual lions. The differences seen between South African and museum samples could be explained by either their geographical separation, differences between historical and current environmental factors, or differences between analytical laboratories. Further analysis of contemporary lion samples across their range will improve the interpretability of results.

Both site 2 and Southern-lion groups were significantly enriched in $\delta^{15} \mathrm{~N}$, and showed a slight, non-significant enrichment in $\delta^{13} \mathrm{C}$. Nutritional stress has been shown to result in increased $\delta^{15} \mathrm{~N}$ compositions in animal tissues (Hobson and Clark 1992; Mizukami et al. 2005; Urton and Hobson 2005). As wild lions can experience long periods of fasting, followed by gorge feeding (Schaller 2009), this may explain the $\delta^{15} \mathrm{~N}$ enrichment seen in some of the wild populations. Although captive individuals can be enriched $\delta^{15} \mathrm{~N}$, this often indicates increased trophic enrichment from domestic food sources (van Schingen et al. 2016). This does not appear to be the case for the captive lions here, which have comparatively depleted $\delta^{15} \mathrm{~N}$. This could suggest that these populations are not experiencing nutritional stress or are potentially consuming food that is isotopically similar in trophic level to wild prey groups. 


\section{Influence of diet}

It has not been possible to determine whether differences in assimilated diet have a significant impact on the diet-tissue enrichment between groups, as both captive and freerange populations plot within the wild lion mixing isospace (Fig. 3). Wild lion groups appear to be influenced to a greater extent by grazing prey animals than by browsers and mixed feeders (Fig. 3). As grazers consume food with a higher C4 content (Ambrose 1986), this may be reflected in the slight $\delta^{13} \mathrm{C}$ enrichment seen in the wild lion samples. Dietary mixing models are sensitive to missing prey groups (Phillips et al. 2014), and as sampling sites span diverse habitats (Fig. 1), prey animal diets will also vary in composition by site. Prey animal baselines are incomplete for sites 1, 2, captive and free-range, so it is not possible to draw conclusive results from the current dietary mixing model.

Isotope data from South African lamb and chicken meat, as well as Namibian and Kenyan donkey samples (see Fig. 3 for details) have also been included for visual comparison with wild prey. The donkey and lamb samples plot firmly within the lion ellipse and mixing isospace (Fig. 3). As the donkey samples originate from outside of South Africa, this highlights the need for additional analysis of food sources to understand lionprey dietary relationships. The lamb sample from the Rûens region in the Western Cape (*A) is isotopically similar to site 4 browsers, with each sharing a close geographical range. The lamb sample from Free State $(* B)$ plots closely to site 2 lions, both of which originate from montane grassland habitats (Fig. 1). Of note, is the exclusion of chicken meat from the dietary mixing isospace. This sample, obtained from a captive lion (zoo) study in Pretoria, is likely the most representative of potential captive lion diets. However, it does not feature within the wild lion mixing isospace, so could be excluded as a potential wild prey source.

To improve the model's accuracy, it will be necessary to include samples that are representative of temporal changes in prey availability, as well as prey from captive populations. The authors have not been able to confirm diets with captive-breeders, or directly sample from breeding facilities. It will be essential to work with captive breeders, to understand the feeding and husbandry conditions of captive lions, and how this is regulated across South Africa's breeding facilities. Although they are thought to utilise domesticated livestock for feeding (NSPCA 2017; Fobar 2019), if breeding facilities were to have access to wild prey, this would negate the accuracy of the method.

\section{Predictive modelling}

The KNN algorithm model was $70 \%$ accurate in predicting wild, captive, free-range and museum groups (Table 3). Of the South African populations, the model had the highest accuracy in identifying free-range groups $(75 \%)$, however this group also had one of the smaller sample sizes prior to data point simulation. When simulated seized samples were applied to the model, the majority (63\%) were classified as wild origin. However, the wild group was also the largest group prior to data simulation and so may be better represented by the model. Additional training samples, including larger sample sizes of raw data, will be required to improve predictive accuracy. 


\section{Impacts on testing}

Comparative testing was used to assess interlaboratory accuracy. Although results are reported against international reference scales, analytical error amongst laboratories may impact trade investigations. In the case of South Africa's legalised lion bone trade, high degrees of accuracy are essential as both captive-bred and wild lions live in close geographic proximity. Furthermore, free-range lions potentially utilise isotopically similar prey groups as wild lions. With potential for geographical and dietary overlaps between wild and captive lions, high analytical accuracy will be necessary when developing methodology to distinguish between populations.

Comparative testing of samples yielded results that are outside the analytical error limits of the other laboratory (see methods, Table 4). A slight enrichment was found in the $\delta^{15} \mathrm{~N}$ composition of samples analysed in South Africa compared to the UK laboratory (Table 4). The mechanisms behind this variation are unclear, as both laboratories followed the same analytical procedures. Variation could be due to the influence of local factors such as site, season and equipment function (Jardine and Cunjak 2005). Additionally, as hair isotope composition varies from root to tip, reflecting nutritional changes during growth (Rysava et al. 2016), sample selection and the degree of homogenisation can lead to inconsistent measurements between repeat samples (Jardine and Cunjak 2005). It is important to note that the sample sizes used in the inter-laboratory comparison are small, with single sample repeats carried out at both laboratories, making effective statistical analysis challenging. Further investigation into the global variance between laboratories may assist in assessing analytical accuracy for trade purposes.

Furthermore, the impact of taxidermy preservation methods on isotopic signatures is unknown. Salt preservation is not believed to significantly impact carbon and nitrogen isotope analysis (Barrow et al. 2008). However, literature on the effects of preservation on isotope composition of hair is limited and often conflicting; depending on tissue type, individual morphological characteristics and the species being tested (Krab et al. 2012). Preservation methods used on the museum samples are also unknown, and the age and storage conditions may have impacted the accuracy of analysis.

\section{Potential for use in trade investigations and enforcement}

This study has shown that the isotopic composition of lion hair in South Africa is distinct from museum samples. However, determining if this variation is due to geographical, dietary or a combination of factors has not been possible. With further analysis of lion populations across their range, this methodology could potentially be applied in wildlife trade investigations. This may be particularly applicable in the domestic and inter-African trade of lion skins and pelts (Williams et al. 2017b).

For SIA to be applied in bone-trade investigations, it will be necessary to test this method on lion bone material. Isotope analysis of bone requires a more time-consuming methodology compared to that of hair, as bone-collagen must first be extracted (O'Connell and Hedges 1999). One potential solution to differentiate between legitimate trade of captive lions and illegal, wild-sourced trade, could be through the development of a detailed $\delta^{13} \mathrm{C}$ and $\delta^{15} \mathrm{~N}$ database of captive and wild populations. A similar, although more extensive approach, has been applied with great success by the African Rhino Specialist Group. Here, the development of a chemical database has been used to successfully identify the origin of rhino horn in trade (Amin et al. 2003). 
Additional isotopic analysis may aid in the differentiation between wild and captive populations. Strontium $\left({ }^{87} \mathrm{Sr} /{ }^{86} \mathrm{Sr}\right)$ and oxygen $\left({ }^{18} \mathrm{O} /{ }^{16} \mathrm{O}\right)$ isotope analysis utilises bone and dental apatite rather than bone-collagen (Slovak and Paytan 2012). Strontium SIA provides a reflection of geological isotopic signatures during bone and dental formation (Slovak and Paytan 2012), this would be potentially applicable if captive-bred lions are fed artificial diets sourced from areas with differing soil and water compositions to wild prey animals. Oxygen SIA reflects climate signatures and may be applicable in assessing the composition of water consumed by lions, particularly if captive-bred lions are provided water that has been processed or treated, differing from natural rainfall water compositions. Although the inclusion of additional isotope testing has the potential to improve the method, fine-scale accuracy is paramount considering the close quarters wild and captive-bred lions occupy throughout South Africa.

Future studies should attempt to incorporate captive lion populations of known origin and feeding history to better understand the metabolic pathways of captive and wild lions. Serial sampling hairs (across the length), rather than our method of homogenisation, may provide a better indication of $\delta^{15} \mathrm{~N}$ enrichment from nutritional stress. Factors including diet, physiology and metabolic rate have been shown to confound isotopic signatures in felid hairs (Pietsch et al. 2011). Understanding lion tissue growth rate, temporal and geographical variations in prey availability, and the effect of captivity on tissue development, will also improve the ability to distinguish between captive and wild groups. In addition, controlled feeding of captive lions, including introducing isotopically homogenous diets or isotope tracers into captive diets, could improve traceability in the lion-bone trade and enable wild and captive individuals to be differentiated with greater success.

The emergence of an international trade of lion bones to Asian markets brings new challenges to lion conservation in Africa. Tools to ensure trade is legitimate and sustainable are essential to address concerns of laundering and poaching of wild populations. This study has found wild lion hair to be significantly enriched in $\delta^{15} \mathrm{~N}$ compared to captive and free-range groups. Wild lion populations also display a greater range in the $\delta^{13} \mathrm{C}$ composition of their hair. These results suggest that origin determination through $\delta^{13} \mathrm{C}$ and $\delta^{15} \mathrm{~N}$ isotope analysis of hair has the potential to be applied to lion-bone samples and may provide a novel tool to confirm the legitimacy and origin of lion bones and derivatives in trade.

Acknowledgements The authors wish to thank the School of Anthropology and Conservation, University of Kent, for providing funding support to A.H. We also thank Drs G. Hall and A.L. Jourdan for their laboratory support. Additionally, we thank Dr S. Miller for her logistical support and the following members of the Lion Management Forum; Mr C. Reynecke (Kariega PGR), Mr L. Eichenberger (Sanbona WR), Mr S. Davidson-Phillips (Welgevonden PGR) and Mr C. Sholto-Douglas (Phinda PGR) for providing samples. We thank Mr H. Bruss (Shemungwe Game Capture) and staff at Karoo Taxidermy and Trans African Taxidermists for providing prey and taxidermy samples. We also thank Mr L. Cruse (UK Border Force) and $\mathrm{Mr}$ M. Cobb (Powell-Cotton Museum) for providing UK samples. We thank the South African Department of Agriculture, Forestry and Fisheries for permitting this study. Finally, we thank the two reviewers whose comments have greatly improved this manuscript.

Author contributions Study design: AH, DLR; fieldwork: AH; data analysis and writing: AH and DLR.

\section{Compliance with ethical standards}

Conflict of interest All authors declare that they have no conflict of interest. 
Ethical approval Permission for the collection of animal specimens was granted by the South African Department of Agriculture, Forestry and Fisheries under Section 20 of the Animal Diseases Act (reference: 12/11/1/8). Field procedures were approved by the University of Kent Ethics Committee (reference: 5-PGT17/18). TOPS Annexure 1 (reference: 04302) and CPF6 (reference: 0135) research permits for the collection and transport of samples were granted by the Gauteng Department of Agriculture and Rural Development.

Open Access This article is licensed under a Creative Commons Attribution 4.0 International License, which permits use, sharing, adaptation, distribution and reproduction in any medium or format, as long as you give appropriate credit to the original author(s) and the source, provide a link to the Creative Commons licence, and indicate if changes were made. The images or other third party material in this article are included in the article's Creative Commons licence, unless indicated otherwise in a credit line to the material. If material is not included in the article's Creative Commons licence and your intended use is not permitted by statutory regulation or exceeds the permitted use, you will need to obtain permission directly from the copyright holder. To view a copy of this licence, visit http://creativecommons.org/licenses/by/4.0/.

\section{References}

Ambrose SH (1986) Stable carbon and nitrogen isotope analysis of human and animal diet in Africa. J Hum Evol 15:707-731

Ambrose SH, DeNiro MJ (1986) The isotopic ecology of East African mammals. Oecologia 69:395-406

Amin R, Bramer M, Emslie R (2003) Intelligent data analysis for conservation: experiments with rhino horn fingerprint identification. Knowl Based Syst 16:329-336

Barrow LM, Bjorndal KA, Reich KJ (2008) Effects of preservation method on stable carbon and nitrogen isotope values. Physiol Biochem Zool 81:688-693

Bauer H, Nowell K, Sillero-Zubiri C, Macdonald DW (2018) Lions in the modern arena of CITES. Conserv Lett 11:e12444

Bega S (2017) Grim toll as captive lions poached, parts used for 'medicine'. IOL Independant Media. https://www.iol.co.za/news/south-africa/gauteng/grim-toll-as-captive-lions-poached-parts-used-formedicine-12329903. Accessed 8 Jan 2018

Blanke C, Chikaraishi Y, Takizawa Y, Steffan S, Dharampal P, Vander Zanden M (2017) Comparing compound-specific and bulk stable nitrogen isotope trophic discrimination factors across multiple freshwater fish species and diets. Can J Fish Aquat Sci 74:1291-1297

Bocherens H, Drucker DG, Bonjean D, Bridault A, Conard NJ, Cupillard C et al (2011) Isotopic evidence for dietary ecology of cave lion (Panthera spelaea) in North-Western Europe: prey choice, competition and implications for extinction. Quatern Int 245:249-261

CITES (2014) CITES Periodic Review of the status of African lion across its range-report of Kenya and Namibia. CITES. https://www.cms.int/sites/default/files/document/ac27_cites_periodic_rev_status_ african_lion_across_range_e.pdf. Accessed 1 July 2019

CITES (2016) CITES Resolution Conf. 17.7; Review of trade in animal specimens reported as produced in captivity. https://www.cites.org/eng/res/index.php. Accessed 4 Jan 2018

CITES (2017) CITES Appendices I, II and III. CITES. https://cites.org/sites/default/files/eng/app/2017/EAppendices-2017-10-04.pdf. Accessed 30 Mar 2018

Coals P, Burnham D, Loveridge A, Macdonald DW, t'Sas-Rolfes M, Williams VL, Vucetich JA (2019) The ethics of human-animal relationships and public discourse: a case study of lions bred for their bones. Animals 9:52

Darimont CT, Paquet PC, Reimchen TE (2007) Stable isotopic niche predicts fitness of prey in a wolf-deer system. Biol J Lin Soc 90:125-137

DEA (2017) Lion export quota for 2017 communicated to the CITES Secretariat in line with CITES requirements. Department of Environmental Affairs Republic of South Africa. https://www. environment.gov.za/mediarelease/lionexportquota_communicatedtocitessecretariat. Accessed 30 Mar 2018

DEA (2018a) Government Gazette No. 41393. Department of Environmental Affairs Republic of South Africa. https://www.environment.gov.za/sites/default/files/gazetted_notices/nemba10of2004_ nondetrimentfindingsGN41393.pdf. Accessed 1 July 2019

DEA (2018b) Minister of Environmental Affairs establishes lion bone export quota for 2018. Department of Environmental Affairs Republic of South Africa. https://www.environment.gov.za/mediarelease/ molewa_establishes_lionboneexportquota2018. Accessed 8 Jan 2018

DeNiro M, Epstein S (1978) Influence of diet on the distribution of carbon isotopes in animals. Geochim Cosmochim Acta 42:495-506 
Deniro MJ, Epstein S (1981) Influence of diet on the distribution of nitrogen isotopes in animals. Geochim Cosmochim Acta 45:341-351

Dittrich C, Struck U, Rödel M-O (2017) Stable isotope analyses-A method to distinguish intensively farmed from wild frogs. Ecol Evol 7:2525-2534

EMS Foundation (2018) The extinction business: South Africa's 'lion' bone trade. The EMS Foundation and Ban Animal Trading. http://emsfoundation.org.za/wp-content/uploads/THE-EXTINCTIONBUSINESS-South-Africas-lion-bone-trade.pdf. Accessed 8 Dec 2018

Environmental Investigation Agency (2017) The Lion's Share: South Africa's trade exacerbates demand for tiger parts and derivatives. https://eia-international.org/wp-content/uploads/The-Lions-Share-FINAL. pdf. Accessed 30 Mar 2018

Erasmus SW, Muller M, van der Rijst M, Hoffman LC (2016) Stable isotope ratio analysis: a potential analytical tool for the authentication of South African lamb meat. Food Chem 192:997-1005

Everatt KT, Kokes R, Lopez Pereira C (2019) Evidence of a further emerging threat to lion conservation; targeted poaching for body parts. Biodivers Conserv 28:4099-4114

Fobar R (2019) Exclusive: inside a controversial South African lion farm. National geographic. https://www. nationalgeographic.co.uk/animals/2019/11/exclusive-inside-controversial-south-african-lion-farm. Accessed 15 Dec 2019

Funston P, Levendal M (2015) Biodiversity management plan for the lion (Panthera leo) in South Africa. Government Gazette, 2. https://www.environment.gov.za/sites/default/files/gazetted_notices/nemba_ africanlion_managementplan_gn351g38706.pdf. Accessed 4 Apr 2018

Hall G (1999) Standard results archive: inter-laboratory comparison of NIST standards. University of Pretoria Mammal Research Institute Isotope Laboratory, Unpublished material

Hall-Martin A, van der Merwe NJ, Lee-Thorp J, Armstrong R, Mehl C, Struben S, Tykot R (1993) Determination of species and geographic origin of rhinoceros horn by isotopic analysis and its possible application to trade control. In: Ryder OA (ed) Proceedings of an international conference: rhinoceros biology and conservation. Zoological Society of San Diego, San Diego, California, p 123-135

Hayward MW, Kerley GIH (2005) Prey preferences of the lion (Panthera leo). J Zool 267:309

Henschel P, Coad L, Burton C, Chataigner B, Dunn A, MacDonald D et al (2014) The lion in West Africa is critically endangered. PLoS ONE 9:e83500

Hinsley A, Rust N (2019) Lion and tiger farming may be inhumane, but we don't know if it increases poaching. The conversation. https://theconversation.com/lion-and-tiger-farming-may-be-inhumanebut-we-dont-know-if-it-increases-poaching-120040. Accessed 15 Dec 2019

Hobson KA (1999) Tracing origins and migration of wildlife using stable isotopes: a review. Oecologia 120:314-326

Hobson KA, Clark RG (1992) Assessing avian diets using stable isotopes I: turnover of ${ }^{13} \mathrm{C}$ in tissues. Condor 94:181-188

Hu Y, Luan F, Wang S, Wang C, Richards MP (2009) Preliminary attempt to distinguish the domesticated pigs from wild boars by the methods of carbon and nitrogen stable isotope analysis. Sci China Ser D 52:85-92

Hurley JM, West JB, Ehleringer JR (2010) Stable isotope models to predict geographic origin and cultivation conditions of marijuana. Sci Justice 50:86-93

Jackson AL, Parnell AC (2011) Comparing isotopic niche widths among and within communities: SIBERStable Isotope Bayesian Ellipses in R. J Anim Ecol 80:595-602

Jardine TD, Cunjak RA (2005) Analytical error in stable isotope ecology. Oecologia 144:528-533

Kawanishi K, Liang S, Darimont C, Reimchen T, Sunquist M (2012) Isotopic niche differentiation among mammals from a rainforest in peninsular Malaysia. Raffles Bull Zool 29:233-239

Kays R, Feranec RS (2011) Using stable carbon isotopes to distinguish wild from captive wolves. Northeast Nat 18:253-264

Krab EJ, Van Logtestijn RSP, Cornelissen JHC, Berg MP (2012) Reservations about preservations: storage methods affect $\delta 13 \mathrm{C}$ signatures differently even in closely related soil fauna: storage effects on $\delta 13 \mathrm{C}$ in related soil fauna. Methods Ecol Evol 3:138-144

Lindsey PA, Alexander R, Balme G, Midlane N, Craig J (2012) Possible relationships between the South African captive-bred lion hunting industry and the hunting and conservation of lions elsewhere in Africa. S Afr J Wildl Res 42:11-22

Meier-Augenstein W (2017) Stable isotope forensics: methods and forensic applications of stable isotope analysis, 2nd edn. Wiley, Chichester. ISBN: 978-1-119-08020-6

Meier-Augenstein W, Schimmelmann A (2019) A guide for proper utilisation of stable isotope reference materials. Isot Environ Health Stud 55(2):13-128

Meier-Augenstein W, Chartrand MMG, Kemp HF, St-Jean G (2011) An inter-laboratory comparative study into sample preparation for both reproducible and repeatable forensic $2 \mathrm{H}$ isotope analysis of human 
hair by continuous flow isotope ratio mass spectrometry: inter-lab human hair $2 \mathrm{H}$ exchange protocol study. Rapid Commun Mass Spectrom 25:3331-3338

Miller SM, Riggio J, Funston P, Power J, Williams V, Child M (2016) A conservation assessment of Panthera leo. In: Child MF, Roxburgh L, Raimondo D, Do Linh San E, Seller J, Davies-Mostert H (eds) The red list of mammals of South Africa, Swaziland and Lesotho. South African National Biodiversity Institute and Endangered Wildlife Trust, Midrand

Mizukami RN, Goto M, Izumiyama S, Hayashi H, Yoh M (2005) Estimation of feeding history by measuring carbon and nitrogen stable isotope ratios in hair of Asiatic black bears. Ursus 16:93-101

Mutirwara R, Radloff FGT, Codron D (2018) Growth rate and stable carbon and nitrogen isotope trophic discrimination factors of lion and leopard whiskers. Rapid Commun Mass Spectrom 32:33-47

NSPCA (2017) DBV SPCA annual report: October 2016-September 2017. NCSPCA. https://nspca.co.za/ wp-content/uploads/2018/03/Annual-Report-2016-2017.pdf. Accessed 30 Mar 2018

NSPCA vs Department of Environmental Affairs (2019) Judgement: lion bone case 86515/2017. https:// conservationaction.co.za/wp-content/uploads/2019/08/Judgment-Lion-Bone-case-6-August-2019-1. pdf. Accessed 10 Dec 2019

O'Connell TC, Hedges RE (1999) Isotopic comparison of hair and bone: archaeological analyses. J Archaeol Sci 26:661-665

O'Connell TC, Hedges RE, Healey MA, Simpson A (2001) Isotopic comparison of hair, nail and bone: modern analyses. J Archaeol Sci 28:1247-1255

Outhwaite W (2018) The legal and illegal trade in African Lions: a study in support of decision 17.241 E. CITES. https://cites.org/sites/default/files/eng/com/ac/30/Inf/E-AC30-Inf-15x.pdf. Accessed 1 Aug 2019

Panthera and WCS (2016) Panthera leo. The IUCN red list of threatened species, version 2019-2. https:// www.iucnredlist.org/species/15951/115130419\#geographic-range Accessed 13 July 2018

Parliament of South Africa (2019) Parliament welcomes colloquium report on captive lion breeding for hunting and lion bone trade. South African Government. https://www.gov.za/speeches/environmentalaffairs-committee-welcomes-adoption-report-colloquium-captive-lion-breeding. Accessed 15 Dec 2019

Parnell A (2016) Simmr: a stable isotope mixing model.

Parng E, Crumpacker A, Kurle CM (2014) Variation in the stable carbon and nitrogen isotope discrimination factors from diet to fur in four felid species held on different diets. J Mammal 95:151-159

PCEA (2018) Adopted report of the PCEA on the colloquium on captive lion breeding for hunting in South Africa: harming or promoting the conservation image of the country. In p. 25. Portfolio Committee on Environmental Affairs, Republic of South Africa. https://conservationaction.co.za/resources/reports/ 11384-2/. Accessed 1 Dec 2019

Phillips DL, Inger R, Bearhop S, Jackson AL, Moore JW, Parnell AC et al (2014) Best practices for use of stable isotope mixing models in food-web studies. Can J Zool 92:823-835

Pietsch SJ, Hobson KA, Wassenaar LI, Tütken T (2011) Tracking cats: problems with placing feline carnivores on $\delta 18 \mathrm{O}, \delta \mathrm{D}$ isoscapes. PLoS ONE 6:e24601

R Core Team (2018) R: A language and environment for statistical computing. R Foundation for Statistical Computing, Vienna, Austria. https://www.R-project.org/

Rauch E, Rummel S, Lehn C, Büttner A (2007) Origin assignment of unidentified corpses by use of stable isotope ratios of light (bio-) and heavy (geo-) elements-a case report. Forensic Sci Int $168: 215-218$

Retief K, West AG, Pfab MF (2014) Can stable isotopes and radiocarbon dating provide a forensic solution for curbing illegal harvesting of threatened cycads? J Forensic Sci 59:1541-1551

Rysava K, McGill RAR, Matthiopoulos J, Hopcraft JGC (2016) Re-constructing nutritional history of Serengeti wildebeest from stable isotopes in tail hair: seasonal starvation patterns in an obligate grazer: nutritional profile of Serengeti wildebeest using N stable isotopes. Rapid Commun Mass Spectrom 30:1461-1468

Schaller GB (2009) The Serengeti lion: a study of predator-prey relations. University of Chicago Press, Chicago

Scientific Authority of SA (2018) National environmental management: biodiversity act: non-detriment finding assessment for Panthera leo (African lion). Department of Environmental Affiars, 21. https:// cer.org.za/wp-content/uploads/2017/12/African-lion.pdf. Accessed 30 Mar 2018

Slovak NM, Paytan A (2012) Applications of Sr isotopes in archaeology. Handbook of environmental isotope geochemistry. Springer, Berlin, pp 743-768

Stewart KM, Bowyer RT, Kie J, Dick BL, Ben-David M (2003) Niche partitioning among mule deer, elk, and cattle: do stable isotopes reflect dietary niche? Écoscience 10:297-302 
Tensen L (2016) Under what circumstances can wildlife farming benefit species conservation? Glob Ecol Conserv 6:286-298

The Nature Conservancy (2009) tnc_terr_ecoregions. The Nature Conservancy, Arlington, VA. https://maps. tnc.org/files/metadata/TerrEcos.xml. Accessed 01 Mar 2020

UNEP-WCMC (2017) CITES Trade Database: Panthera leo (1997-2015 records). CITES Secretariat. https://trade.cites.org/en/cites_trade. Accessed 4 Apr 2018

Urton EJ, Hobson KA (2005) Intrapopulation variation in gray wolf isotope ( $\delta 15 \mathrm{~N}$ and $\delta 13 \mathrm{C})$ profiles: implications for the ecology of individuals. Oecologia 145:316-325

van der Merwe NJ, Lee-Thorp JA, Thackeray JF, Hall-Martin A, Kruger FJ, Coetzee H et al (1990) Sourcearea determination of elephant ivory by isotopic analysis. Nature 346:744-746

Van der Vyver AC (2017) Management plan for the captive lion industry in South Africa. South Africa Predator Association. https://www.sapredators.co.za/images/photos/SAPA-FINAL-MANAGEMENTPLAN-FOR-CAPTIVE-LIONS-Oct2017.pdf. Accessed 4 Apr 2018

van Schingen M, Ziegler T, Boner M, Streit B, Nguyen TQ, Crook V, Ziegler S (2016) Can isotope markers differentiate between wild and captive reptile populations? A case study based on crocodile lizards (Shinisaurus crocodilurus) from Vietnam. Glob Ecol Conserv 6:232-241

Voigt CC, Thalwitzer S, Melzheimer J, Blanc A-S, Jago M, Wachter B (2014) The conflict between cheetahs and humans on Namibian farmland elucidated by stable isotope diet analysis. PLoS ONE 9:e101917

Ward R (1883) The sportsman's handbook to practical collecting, preserving, and artistic setting-up of trophies and specimens. Simpkin, Marshall

Williams V, Newton D, Loveridge A, Macdonald D (2015) Bones of contention: an assessment of the South African trade in African lion Panthera leo bones and other body parts. TRAFFIC \& WildCRU. https:// www.wildcru.org/wp-content/uploads/2015/07/Bones_of_contention.pdf.

Williams V, t'Sas-Rolfes M (2017) SANBI Interim report 1-South African lion bone trade. https:// conservationaction.co.za/resources/reports/sanbi-interim-report-south-african-lion-bone-trade/. Accessed 29 Aug 2018

Williams VL, Loveridge AJ, Newton DJ, Macdonald DW (2017a) A roaring trade? The legal trade in Panthera leo bones from Africa to East-Southeast Asia. PLoS ONE 12:e0185996

Williams VL, Loveridge AJ, Newton DJ, Macdonald DW (2017b) Questionnaire survey of the pan-African trade in lion body parts. PLoS ONE 12:e0187060

Williams V, t'Sas-Rolfes M, Festa-Bianchet M (2019) Born captive: A survey of the lion breeding, keeping and hunting industries in South Africa. PLOS ONE 14(5):e0217409

Yeakel JD, Patterson BD, Fox-Dobbs K, Okumura MM, Cerling TE, Moore JW et al (2009) Cooperation and individuality among man-eating lions. Proc Natl Acad Sci 106:19040-19043

Publisher's Note Springer Nature remains neutral with regard to jurisdictional claims in published maps and institutional affiliations. 